Article type : Original Article

\title{
Evaluation of two autoinducer-2 quantification methods for application in marine
}

\section{environments}

\author{
Tian-Nyu Wang ${ }^{1}$, Anna H. Kaksonen ${ }^{2}$, Pei-Ying Hong ${ }^{1 *}$ \\ ${ }^{1}$ King Abdullah University of Science and Technology (KAUST), Water Desalination and Reuse Center \\ (WDRC), Division of Biological and Environmental Science and Engineering \\ (BESE), Thuwal, 23955-6900, Saudi Arabia \\ ${ }^{2}$ CSIRO Land and Water, 147 Underwood Avenue, Floreat WA 6014, Australia \\ * Corresponding author: \\ Pei-Ying Hong \\ Email: peiying.hong@kaust.edu.sa \\ Phone: +966-12-8082218
}

Running title: Detection methods for AI-2 in marine environments

This article has been accepted for publication and undergone full peer review but has not been through the copyediting, typesetting, pagination and proofreading process, which may lead to differences between this version and the Version of Record. Please cite this article as doi: 10.1111/jam.13725

This article is protected by copyright. All rights reserved. 


\title{
Abstract
}

\begin{abstract}
Aim
This study evaluated two methods, namely high performance liquid chromatography with fluorescence detection (HPLC-FLD) and Vibrio harveyi BB170 bioassay, for autoinducer-2 (AI2) quantification in marine samples. Using both methods, the study also investigated the stability of AI-2 in varying $\mathrm{pH}$, temperature and media, as well as quantified the amount of AI-2 signals in marine samples.
\end{abstract}

\section{Methods and Results}

HPLC-FLD method showed a higher level of reproducibility and precision compared to $V$. harveyi $\mathrm{BB} 170$ bioassay. Alkaline $\mathrm{pH}>8$ and high temperature $\left(>37^{\circ} \mathrm{C}\right)$ increased the instability of AI-2. The AI-2 concentrations in seawater were low, ca. 3.2-27.6 pmol $\mathrm{l}^{-1}$ whereas 8- week old marine biofilm grew on an $18.8 \mathrm{~cm}^{2}$ substratum accumulated ca. $0.207 \mathrm{nmol}$ of AI-2.

\section{Conclusion}

Both methods have pros and cons for AI-2 quantification in marine samples. Regardless, both methods reported a ubiquitous presence of AI- 2 in both planktonic and biomass fractions of seawater, as well as in marine biofilm.

\section{Significance and Impact of the Study}

In this study, AI-2 signals were for the first time enumerated in marine samples to reveal the ubiquitous presence of AI-2 in this environment. The findings suggest a possible role of AI- 2 in biofilm formation in marine environment, and the contribution of AI-2 in biofilm-associated problems such as biofouling and biocorrosion.

Keywords: autoinducer-2; 4,5-dihydroxy-2,3-pentandione; marine biofilm; biofouling 


\section{Introduction}

Bacteria utilize quorum sensing (QS) system to communicate with each other and to coordinate certain behaviors in response of cell density. QS is mediated by small signal molecules named autoinducers. Autoinducers mainly comprise three groups: autoinducer-1 (AI-1), autoinducer-2 (AI-2) and autoinducer peptide (AIP). Among these three identified QS signals, AI-2 is considered as a universal signal that can mediate intra- and interspecies communication among bacteria. This is because all AI-2 signals found to date (Chen et al. 2002; Miller et al. 2004) come from the same precursor named 4,5-dihydroxypentane-2,3-dione (DPD). The ubiquitous biosynthesis pathway of DPD by LuxS enzyme is widely distributed in various Gram-positive and Gram-negative bacteria. Furthermore, DPD signal can spontaneously rearrange into different interconvertible DPD derivatives (Fig. S1) and mediate intra or interspecies QS in different bacteria (Xavier and Bassler 2005; Gonzalez Barrios et al. 2006). DPD and the DPD isomers with AI-2 activity are collectively referred to as AI-2 (Xavier et al. 2007). The feature of AI-2 is in contrast to the intra-species AI-1 (i.e., N-acyl homoserine lactone, AHL) and AIP which are secreted by Gram-negative bacteria and Gram-positive bacteria, respectively.

Through bioinformatics analysis, LuxS/AI-2 is identified to be widely distributed in the marine environment (Bodor et al. 2008; Doberva et al. 2015), implying that AI-2 may be produced by marine microorganisms and can play a potential role in microbial-associated problems (e.g. biofilm formation) prevalent in the seawater application systems. For example, Jahid and coworkers found correlation between AI-2 secretion and biofilm formation by Aeromonas hydrophila in saline media (Jahid et al. 2015). In a separate study, the application of an AI-2 inhibitor was found to reduce biofilm formation in marine strain Halomonas pacifica (Liaqat et al. 2014) and mitigate membrane biofouling in seawater desalination RO system 
(Katebian et al. 2016). Collectively, these studies imply the possibility of AI-2 related biofilm formation in marine environment. However, most of these studies provide qualitative description of the role of AI-2 in marine biofilm formation, and do not quantify the threshold concentration of AI-2 signal molecules associated with these marine biofilms.

The lack of quantitative measurements was probably related to the difficulties associated with AI-2 quantification. The current methods for AI-2 quantification is classified into biologicalbased and chemical-based methods. One of the biological methods is to utilize the marine bacterial reporter Vibrio harveyi BB170 (Bassler et al. 1994) as a biosensor. V. harveyi BB170 was engineered to maintain its AI-2 regulation pathway and to produce bioluminescence in response to AI-2 signal. Past studies showed that the accuracy and reproducibility of this bioassay can be easily affected by the assay conditions (eg. borate concentration, $\mathrm{pH}$, and other growth conditions etc.) and by unknown interference from the culture supernatant (DeKeersmaecker and Vanderleyden 2003; Turovskiy and Chikindas 2006; Vilchez et al. 2007).

Alternatively, AI-2 can also be determined by analytical instruments. So far, there is no existing protocol developed for directive quantification of AI-2 using analytical method (eg. HPLC, GC, HPLC-MS/MS etc.). This is because that DPD is inherently unstable and dynamically changes to its various isomeric forms which complicates direct monitoring. Instead, derivatization helps to convert $\mathrm{AI}-2$ signal pools into a more stable and/or fluorescent form that can be identified or quantified by analytical method such as HPLC-FLD (Song et al. 2014). This analytical method was earlier shown to accurately determine AI-2 in biological samples. However, to date, the method has not been applied to quantify AI-2 in biological samples retrieved from marine environments.

In this study, we aim to evaluate the use of both Vibrio harveyi BB170 bioassay method and

This article is protected by copyright. All rights reserved. 
chemical HPLC-FLD method to quantify AI-2 in marine water and biofilm samples. The stability of AI-2 was first investigated in simulated marine conditions, including high salinity, and with varying temperature and $\mathrm{pH}$. We then demonstrate the use and compared the suitability of the methods to quantify AI-2 signals in marine samples.

\section{Materials and methods}

\section{AI-2 detection by HPLC-FLD method}

AI-2 was detected by determining DPD as surrogate. A standard curve of DPD was prepared by diluting the commercial DPD solutions $\left(3.9 \mathrm{mmol} \mathrm{l}^{-1} \mathrm{DPD}\right.$ in $1 \mathrm{mmol} \mathrm{l}^{-1} \mathrm{KHSO}_{4} \mathrm{pH} 1.5$, Omm Scientific Inc., Dallas, TX) with deionized water to different concentrations ranging from 0.001 $\mu \mathrm{mol} \mathrm{l}^{-1}$ to $200 \mu \mathrm{mol}^{-1}$. DPD concentration was determined in triplicate for each concentration. Derivatization and HPLC analysis were performed as described previously (Song et al. 2014). Briefly, $400 \mu \mathrm{L}$ DPD sample and $400 \mu \mathrm{L}$ Dan solution $\left(0.2 \mathrm{~g} \mathrm{l}^{-1}\right.$ 2,3-Diaminonaphthalene in 0.1 mol $\mathrm{l}^{-1} \mathrm{HCl}$ ) were added to an autosampler vial and mixed for $2 \mathrm{~min}$. This step maintained the final $\mathrm{pH}$ of reaction sample at acidic condition $(<\mathrm{pH} 2)$, which will stabilize AI-2 signals and prevent false positive result caused by carbohydrates in the sample (Song et al. 2014). The vial was then incubated in a water bath at $90^{\circ} \mathrm{C}$ for 40 min to allow the derivatization reaction to proceed (Fig. S2). The short derivatization time was chosen based on findings from (Song et al. 2014) and to ensure that AI-2 does not degrade due to unnecessarily long derivatization duration. After cooling down to room temperature, $20 \mu \mathrm{L}$ of the derivation product was analyzed with a Waters Breeze TM 2 HPLC system equipped with a Binary HPLC pump (Waters 1525), an autosampler (Waters 2707), a phenomenex Luna C18 (2) Column (5 $\mu$ m particle size, 4.6×250 $\mathrm{mm}$ ) and a scanning fluorescence detector (Waters 474) at excitation and emission wavelength of

This article is protected by copyright. All rights reserved. 
$271 \mathrm{~nm}$ and $503 \mathrm{~nm}$, respectively. The separation was carried out at room temperature with a mobile phase flow rate of $0.8 \mathrm{ml} \mathrm{min}^{-1}$ using the following gradient elution profile: $\mathrm{t}=0 \mathrm{~min}, 70 \%$ solution A (HPLC grade water with $0.1 \%$ formic acid), $30 \%$ solution B (HPLC grade acetonitrile); $\mathrm{t}=4 \mathrm{~min}, 70 \%$ solution $\mathrm{A}, 30 \%$ solution $\mathrm{B} ; \mathrm{t}=12 \mathrm{~min}, 35 \%$ solution $\mathrm{A}, 65 \%$ solution $\mathrm{B} ; \mathrm{t}=20 \mathrm{~min}, 35 \%$ solution $\mathrm{A}, 65 \%$ solution $\mathrm{B} ; \mathrm{t}=24 \mathrm{~min}, 70 \%$ solution $\mathrm{A}, 30 \%$ solution $\mathrm{B} ; \mathrm{t}=27 \mathrm{~min}, 70 \%$ solution $\mathrm{A}, 30 \%$ solution $\mathrm{B}$. The derivatization product was detected at a retention time of approximately $9.4 \mathrm{~min}$.

\section{AI-2 detection by Vibrio harveyi BB170 bioassay}

Commercial DPD solution was diluted to various concentrations ranging from $0.001 \mu \mathrm{mol} \mathrm{l}^{-1}$ to $200 \mu \mathrm{mol} \mathrm{l}^{-1}$, and the DPD was determined in triplicate for each concentration. V. harveyi BB170 bioassay was carried out using protocols detailed in a previous study (Bassler et al. 1997) with some modifications. Briefly, the $V$. harveyi $\mathrm{BB} 170$ strain (luxN::tn5Kan) was grown at $30^{\circ} \mathrm{C}$ in autoinducer bioassay (AB) medium (Bassler et al. 1994) for $15 \mathrm{~h}$. The cell culture was then diluted 1:5000 into fresh $\mathrm{AB}$ medium. Subsequently, $180 \mu \mathrm{L}$ of the diluted culture was added with $20 \mu \mathrm{L}$ of sample to be tested for AI-2 concentrations. All samples to be tested, including controls and replicates, were aliquoted into 96 -well plates. The plates were incubated at $30^{\circ} \mathrm{C}$, shaking at $100 \mathrm{rpm}$ for $4 \mathrm{~h}$ and the luminescence response of the biosensor was monitored using Infinite 200 pro microplate reader (Tecan, Männedorf, Switzerland). The AI-2 activity registered by the bioassay method was expressed as the fold induction of the reporter strain in the presence of sample over background control ( $\mathrm{AB}$ medium).

This article is protected by copyright. All rights reserved. 


\section{Evaluation of HPLC-FLD and bioassay methods}

The HPLC-FLD and bioassay methods were evaluated and compared based on linearity, the limit of detection (LOD), the limit of quantification (LOQ), the determination of reproducibility, specificity, and intra-day and inter-day precision. Three independent experiments were carried out. LOD and LOQ of HPLC-FLD method were calculated using the equations 1 and 2, respectively (Shrivastava and Gupta 2011):
$\mathrm{LOD}=3.3^{*}(\mathrm{SD} / \mathrm{S})$
Equation [1]
$\mathrm{LOQ}=10 *(\mathrm{SD} / \mathrm{S})$
Equation [2]

, where SD denotes the standard deviation of y-intercepts of regression lines and S denotes the slope of the calibration curve.

For bioassay method, LOD was defined as the concentration that the fold change of bioluminescence is 1.5 and LOQ was defined as the concentration that show minimum fold change in the calibration curve.

To test the reproducibility of two methods, a standard DPD sample $\left(1 \mu \mathrm{mol} \mathrm{I}^{-1}\right)$ was measured by HPLC-FLD method and bioassay for six times. The relative standard deviation (RSD) of the measured DPD concentrations was calculated using equation 3:

\section{$\mathrm{RSD}=\mathrm{STD} / \mathrm{M} \times 100 \% \quad$ Equation [3]}

, where STD denotes the standard deviation, and M denotes the mean value. The specificity of HPLC-FLD and bioassay methods were investigated by analyzing the following solutions in triplicate: 1) deionized water with $1 \mu \mathrm{mol} \mathrm{l}^{-1} \mathrm{DPD}\left(\mathrm{H}_{2} \mathrm{O}\right.$, salinity: $\left.0 \mathrm{~g} \mathrm{l}^{-1}\right)$; 2) phosphate buffered saline with $1 \mu \mathrm{mol} 1^{-1}$ DPD (PBS: $8 \mathrm{~g} \mathrm{l}^{-1} \mathrm{NaCl}, 0.2 \mathrm{~g} \mathrm{l}^{-1} \mathrm{KCl}, 1.44 \mathrm{~g} \mathrm{l}^{-1} \mathrm{Na}_{2} \mathrm{HPO}_{4}, 0.24 \mathrm{~g} \mathrm{l}^{-1} \mathrm{KH}_{2} \mathrm{PO}_{4}$, $\mathrm{pH}$ adjusted to 6.7 with $\mathrm{HCl}$, salinity: $9.88 \mathrm{~g} \mathrm{l}^{-1}$ ); 3) $50 \mathrm{mmol} \mathrm{l}^{-1}$ Tris- $\mathrm{HCl}$ buffer with $1 \mu \mathrm{mol} \mathrm{l}^{-1}$ DPD (Tris-HCl: $6.06 \mathrm{~g} \mathrm{l}^{-1}$ Tris, $5.84 \mathrm{~g} \mathrm{l}^{-1} \mathrm{NaCl}, 2.03 \mathrm{~g} \mathrm{l}^{-1} \mathrm{MgCl}_{2}, \mathrm{pH}$ adjusted to 7.4 with $\mathrm{HCl}$, 
salinity: $13.93 \mathrm{~g} \mathrm{l}^{-1}$ ); 4) high salinity artificial seawater with $1 \mu \mathrm{mol} \mathrm{l}^{-1}$ DPD (HSAS: $46.24 \mathrm{~g} \mathrm{l}^{-}$ ${ }^{1} \mathrm{NaCl}, 0.74 \mathrm{~g} \mathrm{l}^{-1} \mathrm{KCl}, 0.99 \mathrm{~g} \mathrm{l}^{-1} \mathrm{CaCl}_{2}, 6.09 \mathrm{~g} \mathrm{l}^{-1} \mathrm{MgCl}_{2} \cdot 6 \mathrm{H}_{2} \mathrm{O}$ and $3.94 \mathrm{~g} \mathrm{l}^{-1} \mathrm{MgSO}_{4} .7 \mathrm{H}_{2} \mathrm{O}$, salinity: $58 \mathrm{~g} \mathrm{l}^{-1}$ ); 5) Luria-Bertani medium with $1 \mu \mathrm{mol}^{-1}$ DPD (LB: $10 \mathrm{~g} \mathrm{l}^{-1} \mathrm{NaCl}, 10 \mathrm{~g} \mathrm{l}^{-1}$ tryptone, $5 \mathrm{~g} \mathrm{l}^{-}$ ${ }^{1}$ yeast extract, salinity: $10 \mathrm{~g} \mathrm{l}^{-1}$ ); 6) HSAS-CP medium with $1 \mu \mathrm{mol}^{-1}$ DPD (HSAS-CP: $1 \mathrm{~g} \mathrm{l}^{-}$ ${ }^{1}$ yeast extract, $5 \mathrm{~g} \mathrm{l}^{-1}$ peptone, $46.24 \mathrm{~g} \mathrm{l}^{-1} \mathrm{NaCl}, 0.74 \mathrm{~g} \mathrm{l}^{-1} \mathrm{KCl}, 0.99 \mathrm{~g} \mathrm{l}^{-1} \mathrm{CaCl}_{2}, 6.09 \mathrm{~g} \mathrm{l}^{-}$ ${ }^{1} \mathrm{MgCl}_{2} \cdot 6 \mathrm{H}_{2} \mathrm{O}$ and $3.94 \mathrm{~g} \mathrm{l}^{-1} \mathrm{MgSO}_{4} .7 \mathrm{H}_{2} \mathrm{O}$, salinity: $\left.58 \mathrm{~g} \mathrm{l}^{-1}\right)$. The intra-day precision of the two methods was evaluated by analyzing deionized water samples spiked with different concentrations of DPD $\left(0.6 \mu \mathrm{mol}{ }^{-1}, 1 \mu \mathrm{mol} \mathrm{l}^{-1}, 6 \mu \mathrm{mol} \mathrm{l}^{-1}, 10 \mu \mathrm{mol} \mathrm{l}^{-1}, 20 \mu \mathrm{mol} \mathrm{l}^{-1}\right.$ for HPLCFLD method, or $0.1 \mu \mathrm{mol} \mathrm{l}^{-1}, 0.2 \mu \mathrm{mol} \mathrm{l}^{-1}, 0.4 \mu \mathrm{mol}^{-1}, 0.6 \mu \mathrm{mol}^{-1}, 0.8 \mu \mathrm{mol}^{-1}$ for bioassay) in a single day for three times. The inter-day precision of the two methods were evaluated by determining known concentrations of DPD $\left(1 \mu \mathrm{mol}^{-1}\right.$ and $10 \mu \mathrm{mol}^{-1}$ for HPLC method, or 0.2 $\mu \mathrm{mol} \mathrm{l}^{-1}$ and $0.8 \mu \mathrm{mol} \mathrm{l}^{-1}$ for bioassay) spiked into deionized water for three times on five consecutive days. All the results obtained were evaluated against known spiked concentrations. Statistical analysis was performed using Minitab 17.2 and Origin Pro 2015.

\section{DPD determination in various media at control conditions}

DPD stock solutions were mixed with $1 \mathrm{~mL}$ of the six reagents (i.e., $\mathrm{H}_{2} \mathrm{O}$, PBS, Tris-HCl, HSAS,

LB and HSAS-CP) to obtain a final concentration of $100 \mu \mathrm{mol} \mathrm{l}^{-1}$. Samples were determined immediately by both HPLC-FLD method and bioassay for the DPD concentrations.

\section{DPD stability in various media at elevated temperatures}

The stability of DPD at elevated temperatures was investigated by incubating $100 \mu \mathrm{mol} 1^{-1}$ DPD in $1 \mathrm{~mL}$ of the six above-mentioned media at $37^{\circ} \mathrm{C}$ or $50^{\circ} \mathrm{C}, 200 \mathrm{rpm}$ for $18 \mathrm{~h}$. After incubation,

This article is protected by copyright. All rights reserved. 
DPD samples were determined by HPLC-FLD method or bioassay. HPLC-FLD or bioassay result of $100 \mu \mathrm{mol} 1^{-1}$ DPD in deionized water at $22{ }^{\circ} \mathrm{C}$ and with no incubation was defined as the $100 \%$ baseline positive control, and used for the normalization of all test results.

\section{Stability of DPD at various $\mathrm{pH}$ values}

To test the effect of $\mathrm{pH}$ on the stability of DPD at both $37{ }^{\circ} \mathrm{C}$ and $50{ }^{\circ} \mathrm{C}$, DPD was mixed in HSAS solution to $100 \mu \mathrm{mol} \mathrm{l}^{-1}$ and adjusted to $\mathrm{pH} 2,4,6,7,8,10$ with $1 \mathrm{M} \mathrm{HCl}$ or $\mathrm{NaOH}$. The DPD solutions were incubated at $37{ }^{\circ} \mathrm{C}$ or $50{ }^{\circ} \mathrm{C}$ and the DPD concentrations determined by the HPLC-FLD method and BB170 bioassay at fixed time intervals of $0 \mathrm{~h}, 6 \mathrm{~h}, 12 \mathrm{~h}, 18 \mathrm{~h}, 24 \mathrm{~h}, 30 \mathrm{~h}$, $36 \mathrm{~h}$ and $40 \mathrm{~h}$. HPLC-FLD and BB170 bioassay result of $100 \mu \mathrm{mol} 1^{-1}$ DPD in HSAS (pH 2) at $22^{\circ} \mathrm{C}$ and with no incubation was defined as $100 \%$ baseline positive control, and used for the normalization of all test results.

\section{Quantification of AI-2 concentration in seawater and marine biofilm samples}

Three samples from marine source were tested for AI-2 determination. First, Red Sea water sample S1 was collected from a piped connection at Water Desalination and Reuse Center, KAUST. Another two seawater samples named S2 and S3 came from two different sampling points in a pilot-scale seawater cooling tower (PCT) system located at KAUST's central Utilities Plant (Fig. S3). Sample S2 was obtained from a seawater equalization tank, dosed with antiscaling chemicals (NO.3DT135, Nalco). Sample S3 was obtained from the cooling tower system at the point where heat transfer and recirculation occur. Sampling point for S3 was maintained with $0.2 \mathrm{mg} \mathrm{l}^{-1}$ chlorine. Sample S3 was also determined to contain higher salinity and maintained at higher temperature than S1 and S2. All three samples were sampled twice at

This article is protected by copyright. All rights reserved. 
different times (Table S1).

Seawater samples were prepared for AI-2 determination in the following manner. Samples were first filtered through $0.2 \mu \mathrm{m}$ polyvinylidene fluoride (PVDF) membrane to retain biomass on the membranes. Subsequently, all membrane samples with biomass were aseptically cut into pieces prior to suspension in deionized $\mathrm{H}_{2} \mathrm{O}$, respectively. Suspensions were then ultrasonicated in Q500 sonicator (Qsonica, Newtown, CT) at amplitude 25\%, and at an on-off pulsing interval of $2 \mathrm{~s}$ for $3 \mathrm{~min}$. Sonicated samples were centrifuged at $8000 \mathrm{~g}$ for $10 \mathrm{~min}$. Supernatant of each sample was filtered through $0.2 \mu \mathrm{m}$ cellulose acetate membrane filter and subjected to freezedrying in Alpha 1-2 LD plus (Martin Christ, Germany). Subsequently, the lyophilized content was denoted as the biomass portion associated with the respective seawater sample (Table S1).

Filtrates obtained after the $0.2 \mu \mathrm{m}$ PVDF membrane filtration were subject to Oasis HLB solid phase extraction (SPE) cartridge (Waters, Milford, MA) for AI-2 concentration. The SPE procedure was performed by first conditioning the cartridge with $5 \mathrm{~mL}$ methanol and $5 \mathrm{~mL}$ water. Then $1 \mathrm{~L}$ filtrate was passed through the cartridge. After drying with gas for $30 \mathrm{~min}$, the cartridge was rinsed with $5 \mathrm{~mL}$ water and eluted with $10 \mathrm{~mL}$ methanol with $0.1 \%$ formic acid. The eluted solvents were evaporated with nitrogen, and the residue was denoted as the filtrate portion associated with the respective seawater sample (Table S1).

Recovery efficiency with Oasis HLB cartridge was evaluated by concentrating $35 \mathrm{~mL}$ of 1 $\mu \mathrm{mol} \mathrm{l}^{-1}$ and $0.1 \mu \mathrm{mol} \mathrm{l}^{-1} \mathrm{DPD}$ in deionized water to $3.5 \mathrm{~mL}$. Recovery efficiency was calculated using the equation 4 :

Recovery efficiency $(\%)=\left(\mathrm{DPD}_{\mathrm{S}} \times 3.5\right) /\left(\mathrm{DPD}_{0} \times 35\right) \times 100 \% \quad$ Equation [4] , where $\mathrm{DPD}_{\mathrm{S}}$ and $\mathrm{DPD}_{0}$ stand for the concentration of DPD after and before SPE treatment.

This article is protected by copyright. All rights reserved. 
In addition to seawater samples, marine biofilm samples were grown in a drip flow reactor system for approximately 8 weeks and 10 weeks, and quantified for their AI-2 concentrations. The biofilm was grown on 10 pieces of polyethersulfone ultrafiltration membranes with dimensions of 25 by $75 \mathrm{~mm}$ (GE Osmonics, Boston, MA) that were placed in the 10-channel drip flow reactors (Biosurface Technologies, Bozeman, MT). Fresh seawater collected from Red Sea was pumped into the drip flow reactors at a flow rate of $0.3 \mathrm{~L} \mathrm{~h}^{-1}$, and dripped onto the membrane surface at a $10^{\circ}$ angle. In the $8^{\text {th }}$ week and $10^{\text {th }}$ week of biofilm growth, four pieces of membranes with attached biofilm were collected aseptically and suspended in $200 \mu \mathrm{L}$ deionized water. After sonication for $3 \mathrm{~min}$, the mixture was centrifuged. The supernatant, after filtration by $0.2 \mu \mathrm{m}$ filter, was freeze-dried for AI-2 quantification.

All the treated samples were determined for AI-2 concentration by both HPLC-FLD method and bioassay. Interference peaks were observed near the 9.4 min retention time on HPLC for environmental samples. To facilitate a better identification of DPD-associated peaks, High Performance Liquid chromatography-tandem mass spectrometry (HPLC-MS/MS) was conducted to verify those peaks.

\section{Results}

\section{Evaluation of HPLC-FLD method}

HPLC-FLD based method showed linearity over a broad range of DPD concentrations (Fig. 1A). Two linear regression curves $(\mathrm{H} 1$ and $\mathrm{H} 2)$ covering different ranges of concentrations (0.01-0.4 $\mu \mathrm{mol} \mathrm{l}^{-1}$ and 0.4-100 $\mu \mathrm{mol} \mathrm{l}^{-1}$ ) were defined (Table 1). The two linear fitted lines showed high correlation of determination $\left(\mathrm{R}^{2}=0.998\right)$. The limit of detection (LOD) and limit of quantification (LOQ) of HPLC-FLD method based on $\mathrm{H} 2$ were $11 \mathrm{nmol} \mathrm{l}^{-1}$ and $35 \mathrm{nmol} \mathrm{l}^{-1}$, 
respectively. The peak area in $\mathrm{H} 1$ curve showed higher relative standard deviation (RSD) than that observed in $\mathrm{H} 2$ curve, with a maximum RSD of $88.6 \%$. The limit of linearity (LOL) for HPLC-FLD method was $100 \mu \mathrm{mol} 1^{-1}$. DPD concentration of $\geq 400 \mu \mathrm{mol} 1^{-1}$ saturated the fluorescence detector. For injection repeatability test, determination of $1 \mu \mathrm{mol} 1^{-1}$ DPD by HPLC method denoted $1.04 \pm 0.0059 \mu \mathrm{mol} \mathrm{l}^{-1} \mathrm{DPD}$, with RSD of $0.57 \%$. One $\mu \mathrm{mol} \mathrm{l}^{-1}$ DPD dissolved in $\mathrm{H}_{2} \mathrm{O}$, PBS, Tris-HCl, HSAS, LB, and HSAS-CP was measured by HPLC-FLD method as 1.03 $\pm 0.0051 \mu \mathrm{mol} \mathrm{l}^{-1}, 0.97 \pm 0.0047 \mu \mathrm{mol} \mathrm{l}^{-1}, 1.04 \pm 0.0023 \mu \mathrm{mol} \mathrm{l}^{-1}, 1.07 \pm 0.0073 \mu \mathrm{mol} \mathrm{l}^{-1}, 1.09 \pm$ $0.0074 \mu \mathrm{mol} \mathrm{l}^{-1}$ and $1.07 \pm 0.0016 \mu \mathrm{mol} \mathrm{l}^{-1}$, respectively, with corresponding RSD values of $0.49 \%, 0.48 \%, 0.26 \%, 0.79 \%, 0.67 \%$ and $0.17 \%$, respectively. Intra-day determination of 0.6 $\mu \mathrm{mol} \mathrm{1} \mathrm{l}^{-1}, 1 \mu \mathrm{mol} \mathrm{l}^{-1}, 6 \mu \mathrm{mol} \mathrm{l}^{-1}, 10 \mu \mathrm{mol} \mathrm{l^{-1 }}$ and $20 \mu \mathrm{mol} \mathrm{l^{-1 }}$ DPD using HPLC-FLD method was calculated as $0.62 \pm 0.0181 \mu \mathrm{mol} \mathrm{l}^{-1}, 1.03 \pm 0.0083 \mu \mathrm{mol} \mathrm{l}^{-1}, 5.51 \pm 0.0207 \mu \mathrm{mol} \mathrm{l} \mathrm{l}^{-1}, 10.40 \pm$ $0.1995 \mu \mathrm{mol} \mathrm{l}^{-1}$ and $20.40 \pm 0.3857 \mu \mathrm{mol} \mathrm{l}^{-1}$, respectively, with corresponding RSD values of $2.91 \%, 0.80 \%, 0.37 \%, 1.92 \%$ and $1.89 \%$, respectively. Inter-day precision of HPLC-FLD for 1 $\mu \mathrm{mol} \mathrm{l}^{-1}$ and $10 \mu \mathrm{mol} \mathrm{l}^{-1}$ DPD determination were calculated as $1.09 \pm 0.0384 \mu \mathrm{mol} \mathrm{l}^{-1}$ and $10.41 \pm 0.1246 \mu \mathrm{mol} \mathrm{l}^{-1}$, respectively, with corresponding RSD values of $3.50 \%$ and $1.20 \%$, respectively.

\section{Evaluation of BB170 bioassay method}

The response of $V$. haryeyi BB170 to DPD aqueous solution was linear over a concentration range of $0.08 \mu \mathrm{mol}^{-1}$ to $1 \mu \mathrm{mol} \mathrm{l}^{-1}$ (Fig. 1B). A single linear regression curve B1 covering the entire DPD concentration range of 0.08 to $1 \mu \mathrm{mol} \mathrm{l}^{-1}$ was defined for DPD concentration determination at high correlation of determination $\left(\mathrm{R}^{2}=0.997\right)($ Table 1$)$. The LOD and LOQ of the bioassay were $40 \mathrm{nmol}^{-1}$ and $80 \mathrm{nmol} \mathrm{l}^{-1}$, respectively, and were at least three times higher

This article is protected by copyright. All rights reserved. 
than that for HPLC-FLD method (Fig. 1B). The RSD of the B1 curve in bioassay was also up to three times higher than that of $\mathrm{H} 2$ curve in HPLC-FLD method. At higher concentration range of $1 \mu \mathrm{mol} \mathrm{l}^{-1}$ to $10 \mu \mathrm{mol} \mathrm{l}^{-1}$, the bioassay method did not show linear relationship although the magnitude of fold induction can reflect the relative DPD level among samples (Fig.1B). The fold induction of the bioassay gradually peaked at $10 \mu \mathrm{mol} 1^{-1}$ DPD and stayed similar as DPD concentration increased. For injection repeatability test, the determination of $1 \mu \mathrm{mol} 1^{-1}$ DPD by bioassay was calculated as $1.15 \pm 0.0277 \mu \mathrm{mol} \mathrm{l}^{-1}$, with RSD of $2.41 \%$. One $\mu \mathrm{mol} \mathrm{l}^{-1} \mathrm{DPD}$ dissolved in $\mathrm{H}_{2} \mathrm{O}$, PBS, Tris-HCl, HSAS, LB, and HSAS-CP determined by the bioassay method was calculated as $1.21 \pm 0.0085 \mu \mathrm{mol} \mathrm{l}^{-1}, 1.48 \pm 0.0119 \mu \mathrm{mol} \mathrm{l}^{-1}, 1.12 \pm 0.0115 \mu \mathrm{mol} \mathrm{l} \mathrm{l}^{-1}, 1.06 \pm$ $0.0439 \mu \mathrm{mol} \mathrm{l}^{-1}, 0.06 \pm 0.0029 \mu \mathrm{mol} \mathrm{l^{-1 }}$ and $0.15 \pm 0.0109 \mu \mathrm{mol} \mathrm{l}^{-1}$, respectively with the corresponding RSD values of $0.70 \%, 0.80 \%, 1.04 \%, 4.12 \%, 4.47 \%$ and $7.13 \%$, respectively. Intra-day determination of $0.1 \mu \mathrm{mol} 1^{-1}, 0.2 \mu \mathrm{mol} \mathrm{l}^{-1}, 0.4 \mu \mathrm{mol} \mathrm{l}^{-1}, 0.6 \mu \mathrm{mol} \mathrm{l}^{-1}$ and $0.8 \mu \mathrm{mol} \mathrm{l}^{-1}$ DPD using the bioassay method was calculated as $0.15 \pm 0.0015 \mu \mathrm{mol} 1^{-1}, 0.23 \pm 0.0060 \mu \mathrm{mol} 1^{-1}$,

$0.46 \pm 0.080 \mu \mathrm{mol} \mathrm{l} \mathrm{l}^{-1}, 0.81 \pm 0.022 \mu \mathrm{mol} \mathrm{l}^{-1}$ and $0.94 \pm 0.011 \mu \mathrm{mol} \mathrm{l}^{-1}$, respectively with the corresponding RSD values of $0.97 \%, 2.49 \%, 17.25 \%, 2.72 \%$ and $1.19 \%$, respectively. Inter-day precision of the bioassay method for $0.2 \mu \mathrm{mol} \mathrm{l}^{-1}$ and $0.8 \mu \mathrm{mol} \mathrm{l}^{-1} \mathrm{DPD}$ was calculated as $0.24 \pm$ $0.0274 \mu \mathrm{mol} \mathrm{l}^{-1}$ and $1.00 \pm 0.1045 \mu \mathrm{mol} 1^{-1}$, respectively with the corresponding RSD values of $11.415 \%$ and $10.42 \%$, respectively.

\section{DPD determination in various media at control conditions}

One hundred $\mu \mathrm{mol} 1^{-1}$ DPD dissolved in deionized water, PBS, Tris-HCl, HSAS, LB, and HSAS$\mathrm{CP}$ at $22^{\circ} \mathrm{C}$ was determined by the HPLC-FLD and the bioassay methods. The concentration of DPD calculated by the HPLC-FLD method was unaffected by the matrix (One-way ANOVA, p>

This article is protected by copyright. All rights reserved. 
0.05) (Fig. 2A). For the AI-2 bioassay method, Tris- $\mathrm{HCl}$ and $\mathrm{PBS}$ did not have great impact on DPD determination ( $p>0.05$ ), while HSAS, LB and HSAS-CP caused great interference to DPD determination $(\mathrm{p}<0.05)$. Relative bioluminescence of DPD in HSAS decreased to 59\%, and DPD in LB and HSAS-CP resulted in only $24 \%$ and $26 \%$ of bioluminescence compared with DPD in deionized water (Fig. 2B). Dilution of the test solutions improved the accuracy of bioassay method (Fig. 2C), but diluted LB medium and HSAS-CP resulted in a significantly higher relative bioluminescence compared to the other diluted media (One-way ANOVA, p < $0.05)$.

\section{Stability of DPD in various media at elevated temperatures}

When determined by the HPLC-FLD method, DPD concentration remained stable in deionized water and HSAS after $18 \mathrm{~h}$ incubation at $37^{\circ} \mathrm{C}$ and $50{ }^{\circ} \mathrm{C}$ (Fig. 2A). DPD concentrations in all other solutions decreased to varying extent as temperature increased from $22{ }^{\circ} \mathrm{C}$ to 37 or $50{ }^{\circ} \mathrm{C}$. Temperature caused a significant effect on DPD stability when determined by the HPLC-FLD method (One-way ANOVA, $\mathrm{p}<0.05$ ). Based on the HPLC-FLD method, DPD concentration dropped to $73 \%$ and $47 \%$ after $18 \mathrm{~h}$ incubation in HSAS-CP and LB media, respectively at $37^{\circ} \mathrm{C}$ compared to $22^{\circ} \mathrm{C}$. The stability of DPD was 3.3 and 8.1 times higher in Tris- $\mathrm{HCl}(\mathrm{pH} 7.4)$ buffer than in PBS buffer $(\mathrm{pH} 6.7)$ at $37^{\circ} \mathrm{C}$ and $50^{\circ} \mathrm{C}$. However, the same trend was not observed when DPD was determined based on bioassay method, and the DPD concentrations determined in different media at $37^{\circ} \mathrm{C}$ were not significantly different (One-way ANOVA, p > 0.05) (Fig. 2B). The same trend as that observed by HPLC-FLD method was only reproduced by bioassay method when samples were diluted prior to detection (Fig. 2C).

This article is protected by copyright. All rights reserved. 


\section{The stability of DPD in HSAS at various pH values}

The stability of DPD over time at various $\mathrm{pH}$ values and high temperatures was determined using the HPLC-FLD method. At time $=0 \mathrm{~h}, \mathrm{DPD}$ concentration at $\mathrm{pH}$ from 2 to 8 was at $100 \%-110 \%$. However, the DPD concentration decreased to $77 \%$ when dissolved at $\mathrm{pH} 10$. DPD was highly stable in acidic $\mathrm{pH}$ as $100 \%$ of DPD concentration was determined in $\mathrm{pH}$ range from 2 to 6 after $40 \mathrm{~h}$ incubation at $37^{\circ} \mathrm{C}$ (Fig. 3A), and more than $87 \%$ DPD concentration remained after $40 \mathrm{~h}$ incubation at $50^{\circ} \mathrm{C}$ for the same $\mathrm{pH}$ range of 2 to 6 (Fig. 3B). The DPD instability increased at neutral and alkaline $\mathrm{pH}$ over time. DPD was completely inactivated at $\mathrm{pH} 10$ within $6 \mathrm{~h}$ incubation at $37^{\circ} \mathrm{C}$ and $50^{\circ} \mathrm{C}$. Similar observations were made using the bioassay method (Fig. 3C and 3D), and it was observed that the decrease in DPD was more apparent at all tested $\mathrm{pH}$ ranges when measured by the bioassay method than when determined by the HPLC-FLD method. To exemplify, no bioluminescence representative of DPD was detected by bioassay method at $\mathrm{pH} 10$ at time $=0 \mathrm{~h}$. While DPD concentrations remained stable in acidic $\mathrm{pH}$ when quantified by HPLC-FLD method, the bioassay showed a decreased trend for DPD at acidic $\mathrm{pH}$.

\section{Determination AI-2 concentration in marine samples}

Based on the HPLC-FLD method, AI-2 concentrations in the biomass portion of S1, S2 and S3 were 0.4-0.6 pmol 1-1 $5.4-6.3 \mathrm{pmol} \mathrm{l}^{-1}$ and 4.8-8.7 $\mathrm{pmol} \mathrm{l}^{-1}$, respectively (Fig. 4A), while AI-2 concentration in the biomass from S1, S2 and S3 were 0.9-8.0 $\mathrm{pmol} \mathrm{1}^{-1}, 2.8-79.5 \mathrm{pmol}^{-1}$ and 27.4-29.6 pmol $^{-1}$ ), respectively after bioassay determination (Fig. 4B). HPLC-FLD result reveals the free AI-2 concentration in the bulk water phase (i.e., filtrate) were 2.6-5.0 pmol 1-1, 2.4-3.9 pmol $^{-1}$ and 5.1-18.9 pmol $^{-1}$ for S1, S2 and S3, respectively (Fig. 4A). AI-2 bioassay of and filtrate phases of the S1, S2 and S3-2 were 5.0-20.8 $\mathrm{pmol} \mathrm{l}^{-1}$, 103.3-129.9 $\mathrm{pmol} \mathrm{l}^{-1}$ and 19.3

This article is protected by copyright. All rights reserved. 
pmol $1^{-1}$, except for S3-1 filtrate where no bioluminescence was detected (Fig. 4B). Given that the recovery efficiencies of SPE cartridge for $1 \mu \mathrm{mol} \mathrm{l}^{-1}$ DPD solution and $0.1 \mu \mathrm{mol} \mathrm{l}^{-1}$ DPD solution were only $19.13 \%$ and $50.31 \%$, respectively, the actual concentration of AI-2 in filtrate samples could be higher than the detected amount. Four membranes with 8-week old marine biofilm established on membrane surfaces in a DFR reactor were determined to have an average AI-2 amount of $0.104 \pm 0.018 \mathrm{nmol}$ and $0.236 \pm 0.081 \mathrm{nmol}$ by the HPLC-FLD and the bioassay method, respectively. As the biofilm grew to 10-week old, AI-2 amount increased to $0.207 \pm$ $0.055 \mathrm{nmol}$ and $0.242 \pm 0.014 \mathrm{nmol}$, respectively by these two methods (Fig. 5).

\section{Discussion}

Determining AI-2 concentration in the marine habitats is essential to facilitate our understanding on the possible roles of AI-2-related QS activity in marine bacterial community. However, to date, limited studies are available to provide an indication on the range of concentrations of AI-2 in seawater environment or marine community habitat. To address these knowledge gaps, two AI-2 determination methods, namely the HPLC-FLD and the $V$. harveyi BB170 bioassay, were first assessed and compared for their efficacy in detecting AI-2 in conditions that simulate the marine environments. Both methods were then used to evaluate the stability of AI-2 at high temperatures, over a wide range of $\mathrm{pH}$ and in various media, including those of high salinity. It was observed that both AI-2 determination methods showed pros and cons (Table 2). Specifically, the HPLC-FLD method had a broader linear range in AI-2 determination than the bioassay method. The LOD and LOQ of the HPLC-FLD method were $11 \mathrm{nmol}^{-1}$ and $35 \mathrm{n} \mathrm{mol} \mathrm{l}^{-}$ ${ }^{1}$, respectively, and were approximately of the same magnitude $\left(7.6 \mathrm{n} \mathrm{mol}^{-1}\right.$ and $\left.23.0 \mathrm{n} \mathrm{mol}{ }^{-1}\right)$ as those reported in an earlier study (Song et al. 2014). In addition, the HPLC-FLD method was

This article is protected by copyright. All rights reserved. 
able to generate comparatively more accurate and reproducible results, as evidenced from the lower relative standard deviations compared with the bioassay method. Other chemical methods using Gas Chromatography-Mass spectrometry (GC-MS) (Thiel et al. 2009) or HPLC-MS/MS method (Xu et al. 2016) also showed good reproducibility for AI-2 quantification. The bioassay method, in contrast, exhibited low accuracy and reproducibility, particularly when AI-2 concentrations were in the high range and would require pre-dilution of samples. At high concentrations of DPD (e.g. $>1 \mu \mathrm{mol} \mathrm{l}^{-1}$ ), the standard curve of the bioassay shows a sigmoid trend (Figure 1B), which suggest cooperative binding of the luciferase. An earlier study observed that the increase in luminescence by Vibrio fisheri with AHL concentrations also followed a pattern that fit into a cooperative binding model (Perez and Hagen 2010), and that luminescence signals saturate at high concentrations of AHL. This deviation from the linearity of quantification would mean that bioassay method is not suitable for determining samples with high AI-2 concentrations. Furthermore, unlike the HPLC-FLD method, the standard curve for the bioassay method has to be created for each new determination trial to alleviate problems associated with the low reproducibility of this method.

The bioassay method was also more affected by $\mathrm{pH}$ and salinity associated with the samples, reiterating findings obtained from earlier studies that suggested bioassay methods to be detrimentally impacted by the assay conditions. The quantification of $100 \mu \mathrm{mol} \mathrm{l}^{-1} \mathrm{DPD}$ in $\mathrm{H}_{2} \mathrm{O}$, PBS, Tris-HCl, HSAS, LB, HSAS-CP by the HPLC-FLD method was unaffected by the type of matrix (Fig. 2A). However, the relative DPD concentrations in HSAS, LB and HSAS-CP were calculated to decrease to $58 \%, 24 \%$ and $26 \%$, respectively in comparison with the concentration of DPD in $\mathrm{H}_{2} \mathrm{O}$ (i.e., control) when the bioassay method was used (Fig. 2B). Instead, DPD samples had to be diluted 100-fold prior to bioassay method to show similar trend with the ones

This article is protected by copyright. All rights reserved. 
determined by HPLC-FLD (Fig. 2C). This suggested that samples diluted to the linearity range for BB170 assay can be beneficial for DPD quantification; and that sample dilution minimizes the interference effects and improves the overall reproducibility of the bioassay method (Taga and Xavier 2011). However, there are two exceptions where the concentrations of DPD diluted in LB and HSAS-CP medium increased to $142 \%$ and $140 \%$ compared with control. The false positive result was probably caused by DPD analog formation by carbohydrate present in the complex matrices (Thiel et al. 2009).

In general, the stability of DPD at elevated temperatures of $37^{\circ} \mathrm{C}$ and $50^{\circ} \mathrm{C}$ depends on the media. According to the HPLC-FLD method, $100 \mu \mathrm{mol}^{-1}$ DPD in $\mathrm{H}_{2} \mathrm{O}$ and HSAS was stable after $18 \mathrm{~h}$ incubation under $37^{\circ} \mathrm{C}$ and $50^{\circ} \mathrm{C}$. However, when in PBS, Tris- $\mathrm{HCl}, \mathrm{LB}$ and HSAS-CP, $18 \mathrm{~h}$ incubation of the samples at $37^{\circ} \mathrm{C}$ resulted in $26 \%, 88 \%, 47 \%$ and $73 \%$ of DPD concentrations, respectively compared to the control. When incubated at $50^{\circ} \mathrm{C}$, the instability of DPD was further aggravated in these four media. These findings suggested an interactive effect between the solution matrix and temperature, although the exact mechanisms behind accelerated degradation of DPD under these factors remain unknown.

DPD exhibited stability in HSAS at acidic $\mathrm{pH}(\mathrm{pH} 2-6)$ but as $\mathrm{pH}$ increased, the DPD concentration decreased with time. Previously, Globisch et al. showed DPD appeared in different isomers in aqueous solution and the composition of the isomers was closely dependent on $\mathrm{pH}$. The adjustment of $\mathrm{pH}$ from alkaline to acidic range was further demonstrated to recover DPD activity (Globisch et al. 2012). However, our study showed irreversible inactivation of DPD in alkaline $\mathrm{pH}$. Nevertheless, seawater usually has a relatively high boric acid content, and binding borate to DPD would lead to the formation of relative stable cyclic borate AI-2 molecule, thus increasing the life time of DPD in marine environment. However, AI-2 concentration in marine

This article is protected by copyright. All rights reserved. 
environment has not been reported extensively and remains to be elucidated.

To address this knowledge gap, the methods evaluated in this study were used to detect and quantify AI-2 concentrations in various types of seawater samples. To make sure that the AI-2 concentrations falls within the detection range of both methods, the marine samples were concentrated by lyophilization for the biomass portion or SPE for the filtrate portion. SPE was applied to concentrate AI-2 in filtrate as it can remove the excess salt in the seawater samples. Our study showed recovery efficiency of SPE varied across the different batches of samples. This was probably due to the high polarity and water solubility of AI-2 signals (Thiel et al. 2009; Pereira et al. 2013). The combination of these two factors would mean that a good interaction between the signals and SPE column cannot be easily established, and that AI-2 signals may be unintentionally eluted away when performing column washing steps to get rid of accumulated salts from seawater samples. Regardless, AI-2 was detected from both biomass and filtrate of seawater samples using HPLC-FLD method (Fig. 4A). This suggested that AI-2 signal molecules exist intracellularly in marine bacterial community and are subsequently excreted to the environment. AI-2 concentration measured in all samples collected from the marine environment was in pmol $\mathrm{l}^{-1}$ level (ranges from 3.2-27.6 $\mathrm{pmol}^{-1}$ based on the HPLC-FLD result), which is lower from the AI-2 concentration detected in the pure strain cultures (e.g. $1.95 \mu \mathrm{mol} \mathrm{l}^{-1}$ reported for $V$. harveyi and $0.26 \mu \mathrm{mol} \mathrm{l}^{-1}$ reported for Streptococcus mutans) (Thiel et al. 2009). It was previously reported that the minimum working concentration for AI- 2 required to trigger biofilm formation of LuxS-deficient oral commensal bacteria was $0.08 \mathrm{nmol} \mathrm{l}^{-1}$ (Rickard et al. 2006). Hence, it is unlikely that the amount of AI-2 in seawater is able to trigger QS activity given the low concentration. However, when the planktonic cells adhere on surfaces and accumulate, the total AI-2 concentration would likely increase with time, and accelerate biofilm formation 
process. To exemplify, the total amount for AI-2 in $20 \mathrm{~L}$ planktonic phase of S1 sample was calculated to be $0.008-0.013 \mathrm{nmol}$. In contrast, the detected AI- 2 amount in the $10^{\text {th }}$ week biofilm was approximately 16 times higher $(0.207 \mathrm{nmol})$. This accumulation of AI-2 in bacteria was also observed by Xavier and Bassler in an earlier study, which noted that AI-2 accumulation was proportional to cell numbers, and that as long as the AI-2 producing cells grow, AI-2 will continue to be produced due to metabolic process (Xavier and Bassler 2003). These AI-2 signals were observed to accumulate to threshold concentrations when associated with biofilm as young as 8 weeks old, suggesting an either consequential or causative effect imposed by AI- 2 in biofilm formation. So far, the mostly widely studied AHL family was show to play main role in marine biofilm formation (Hmelo 2017). Although not deeply explored, AI-2 with the interspecies feature may have greater impact on mixed bacteria community in marine habitat. Further studies should aim to utilize these methods to detect and quantify AI-2 in a larger set of marine samples, and to provide a mechanistic understanding on the role of AI-2 in the marine environment.

In summary, our study demonstrated the use of two methods, namely the HPLC-FLD and the BB170 bioassay methods to detect AI-2 concentrations in the marine environment. Specifically, the HPLC-FLD provides more reproducible and precise measurements than the bioassay method regardless of the media, $\mathrm{pH}$ and temperature. When further applied to detect for AI-2 signals in the planktonic and biomass phase of seawater as well as that associated with marine biofilm, both methods showed the ubiquitous presence of AI-2 signals in the marine environment.

This article is protected by copyright. All rights reserved. 


\section{Acknowledgement}

The work was funded by King Abdullah University of Science and Technology (KAUST) Competitive Research Grant 2017 (URF/1/2982-01-01) awarded to Pei-Ying Hong. CSIRO Land and Water is thanked for support to Anna Kaksonen.

\section{Conflict of interest}

The authors declare no conflict of interest.

\section{Figures legend}

Figure 1. The determination of the standard limit of detection by (A) HPLC-FLD (B) bioassay method. Data are the mean of three independent experiments, and vertical bars indicate the standard deviations.

Figure 2. Stability of $100 \mu \mathrm{mol} \mathrm{l} \mathrm{l}^{-1} \mathrm{DPD}$ after $18 \mathrm{~h}$ incubation in various media solutions at different temperatures, and measured by (A) HPLC-FLD method, (B) bioassay method, and (C) bioassay method with sample dilution $\left(\square 22^{\circ} \mathrm{C}, 0 \mathrm{~h} ; \square 37^{\circ} \mathrm{C}, 18 \mathrm{~h} ; \square 50^{\circ} \mathrm{C}, 18 \mathrm{~h}\right.$ ).

$\mathrm{H}_{2} \mathrm{O}$ : Milli-Q water; PBS: phosphate buffer saline, $\mathrm{pH}$ 6.7; Tris-HCl: Tris- $\mathrm{HCl}$ buffer, $\mathrm{pH}$ 7.4; HSAS: high salinity artificial seawater; LB: Luria-Bertani medium; HSAS-CP: HSAS-CP medium consisting of $1 \mathrm{~g}$ yeast extract and $5 \mathrm{~g}$ peptone in $1 \mathrm{~L}$ of HSAS. HPLC-FLD or bioassay result (with or without dilution) of $100 \mu \mathrm{mol} 1^{-1} \mathrm{DPD}$ in milli-Q water at $22^{\circ} \mathrm{C}$, time $=0 \mathrm{~h}$ was defined as $100 \%$, respectively.

Figure 3. Stability of $100 \mu \mathrm{mol} 1^{-1}$ DPD in HSAS at various $\mathrm{pH}$ values at different time intervals under (A) $37^{\circ} \mathrm{C}$, and (B) $50^{\circ} \mathrm{C}$ measured by HPLC-FLD method. Stability of $100 \mu \mathrm{mol} 1^{-1} \mathrm{DPD}$ in $\mathrm{HSAS}$ at various $\mathrm{pH}$ values at different time intervals under $(\mathrm{C}) 37^{\circ} \mathrm{C}$, and (D) $50^{\circ} \mathrm{C}$ measured by BB170 bioassay. HPLC-FLD and bioassay result of $100 \mu \mathrm{mol} 1^{-1} \mathrm{DPD}$ in HSAS (pH 2) at $22^{\circ} \mathrm{C}$, time $=0 \mathrm{~h}$ was defined as $100 \%$, respectively $(\bullet \mathrm{pH}=2 ; \times \mathrm{pH}=4 ; \square \mathrm{pH}=6 ; \triangle \mathrm{pH}=7 ; *$ $\mathrm{pH}=8 ; \quad \boldsymbol{\Delta} \mathrm{pH}=10)$.

This article is protected by copyright. All rights reserved. 
Figure 4. AI-2 concentration in both biomass and planktonic (filtrate) portion of seawater S1, S2 and S3, collected at different time and determined by (A) HPLC-FLD method and (B) bioassay method ( $\square$ biomass; $\square$ filtrate).

Figure 5. AI-2 quantity in 8-weeks old and 10-weeks old marine biofilms grown in drip flow reactor by HPLC-FLD and bioassay methods ( $\square$ bioassay; $\square$ HPLC-FLD).

\section{References}

Bassler, B.L., Greenberg, E.P. and Stevens, A.M. (1997) Cross-species induction of luminescence in the quorum-sensing bacterium Vibrio harveyi. J Bacteriol 179, 4043-4045.

Bassler, B.L., Wright, M. and Silverman, M.R. (1994) Multiple signalling systems controlling expression of luminescence in Vibrio harveyi: sequence and function of genes encoding a second sensory pathway. Mol Microbiol 13, 273-286.

Bodor, A., Elxnat, B., Thiel, V., Schulz, S. and Wagner-Doebler, I. (2008) Potential for luxS related signalling in marine bacteria and production of autoinducer- 2 in the genus Shewanella. BMC Microbio/ 8. Chen, X., Schauder, S., Potier, N., Van Dorsselaer, A., Pelczer, I., Bassler, B.L. and Hughson, F.M. (2002) Structural identification of a bacterial quorum-sensing signal containing boron. Nature 415, 545-549. DeKeersmaecker, S.C.J. and Vanderleyden, J. (2003) Constraints on detection of autoinducer-2 (Al-2) signalling molecules using Vibrio harveyi as a reporter. Microbiol-Sgm 149, 1953-1956.

Doberva, M., Sanchez-Ferandin, S., Toulza, E., Lebaron, P. and Lami, R. (2015) Diversity of quorum sensing autoinducer synthases in the Global Ocean Sampling metagenomic database. Aquat Microb Ecol 74, 107-119.

Globisch, D., Lowery, C.A., McCague, K.C. and Janda, K.D. (2012) Uncharacterized 4,5-dihydroxy-2,3pentanedione (DPD) molecules revealed through NMR spectroscopy: implications for a greater signaling diversity in bacterial species. Angew Chem Int Ed Engl 51, 4204-4208.

Gonzalez Barrios, A.F., Zuo, R., Hashimoto, Y., Yang, L., Bentley, W.E. and Wood, T.K. (2006) Autoinducer 2 controls biofilm formation in Escherichia coli through a novel motility quorum-sensing regulator (MqsR, B3022). J Bacterio/ 188, 305-316.

Hmelo, L.R. (2017) Quorum sensing in marine microbial environments. Ann Rev Mar Sci 9, 257-281. Jahid, I.K., Mizan, M.F.R., Ha, A.J. and Ha, S.D. (2015) Effect of salinity and incubation time of planktonic cells on biofilm formation, motility, exoprotease production, and quorum sensing of Aeromonas hydrophila. Food Microbiol 49, 142-151.

Katebian, L., Gomez, E., Skillman, L., Li, D., Ho, G. and Jiang, S.C. (2016) Inhibiting quorum sensing pathways to mitigate seawater desalination RO membrane biofouling. Desalination 393, 135-143. Liaqat, I., Bachmann, R.T. and Edyvean, R.G.J. (2014) Type 2 quorum sensing monitoring, inhibition and biofilm formation in marine microrganisms. Curr Microbiol 68, 342-351.

Miller, S.T., Xavier, K.B., Campagna, S.R., Taga, M.E., Semmelhack, M.F., Bassler, B.L. and Hughson, F.M. (2004) Salmonella typhimurium recognizes a chemically distinct form of the bacterial quorum-sensing signal Al-2. Mol Cell 15, 677-687.

Pereira, C.S., Thompson, J.A. and Xavier, K.B. (2013) Al-2-mediated signalling in bacteria. Fems Microbiol Rev 37, 156-181.

Perez, P.D. and Hagen, S.J. (2010) Heterogeneous response to a quorum-sensing signal in the luminescence of individual Vibrio fischeri. Plos One 5, e15473.

This article is protected by copyright. All rights reserved. 
Rickard, A.H., Palmer, R.J., Blehert, D.S., Campagna, S.R., Semmelhack, M.F., Egland, P.G., Bassler, B.L. and Kolenbrander, P.E. (2006) Autoinducer 2: a concentration-dependent signal for mutualistic bacterial biofilm growth. Mol Microbiol 60, 1446-1456.

Shrivastava, A. and Gupta, V. (2011) Methods for the determination of limit of detection and limit of quantitation of the analytical methods. Chron Young Sci 2, 21.

Song, X.N., Qiu, H.B., Xiao, X., Cheng, Y.Y., Li, W.W., Sheng, G.P., Li, X.Y. and Yu, H.Q. (2014)

Determination of autoinducer- 2 in biological samples by high-performance liquid chromatography with fluorescence detection using pre-column derivatization. J Chromatogr A 1361, 162-168.

Taga, M.E. and Xavier, K.B. (2011) Methods for analysis of bacterial autoinducer-2 production. Curr Protoc Microbio/ Chapter 1, Unit1C 1.

Thiel, V., Vilchez, R., Sztajer, H., Wagner-Dobler, I. and Schulz, S. (2009) Identification, quantification, and determination of the absolute configuration of the bacterial quorum-sensing signal autoinducer-2 by gas chromatography-mass spectrometry. Chembiochem 10, 479-485.

Turovskiy, Y. and Chikindas, M.L. (2006) Autoinducer-2 bioassay is a qualitative, not quantitative method influenced by glucose. J Microbiol Methods 66, 497-503.

Vilchez, R., Lemme, A., Thiel, V., Schulz, S., Sztajer, H. and Wagner-Dobler, I. (2007) Analysing traces of autoinducer-2 requires standardization of the Vibrio harveyi bioassay. Anal Bioanal Chem 387, 489-496. Xavier, K.B. and Bassler, B.L. (2003) LuxS quorum sensing: more than just a numbers game. Curr Opin Microbiol 6, 191-197.

Xavier, K.B. and Bassler, B.L. (2005) Interference with Al-2-mediated bacterial cell-cell communication. Nature 437, 750-753.

Xavier, K.B., Miller, S.T., Lu, W.Y., Kim, J.H., Rabinowitz, J., Pelczer, I., Semmelhack, M.F. and Bassler, B.L. (2007) Phosphorylation and processing of the quorum-sensing molecule autoinducer-2 in enteric bacteria. Acs Chem Biol 2, 128-136.

Xu, F., Song, X., Cai, P., Sheng, G. and Yu, H. (2016) Quantitative determination of Al-2 quorum-sensing signal of bacteria using high performance liquid chromatography-tandem mass spectrometry. $J$ Environ Sci-China.

This article is protected by copyright. All rights reserved. 
Table 1. Parameters determined for the HPLC-FLD and the bioassay method after three independent experiments.

\begin{tabular}{lll}
\hline Name & HPLC-FLD & $\begin{array}{l}\text { Bioassay method by Vibrio } \\
\text { harveyi BB170 }\end{array}$ \\
\hline Efficiency & $\begin{array}{l}\text { Needs derivatization }(40 \mathrm{~min}) \\
\text { before analysis } \\
\text { Read time: } 1 \mathrm{sample} / 27 \mathrm{~min}\end{array}$ & Read time: 96 well plate/2 min \\
\hline Detection limit & $0.11-200 \mu \mathrm{mol} \mathrm{l}^{-1}$ & $0.04-10 \mu \mathrm{mol} \mathrm{l}^{-1}$ \\
\hline Linear range & $0.4-100 \mu \mathrm{mol} \mathrm{l}^{-1}$ & $0.08-1 \mu \mathrm{mol} \mathrm{l}^{-1}$ \\
\hline Interference & $\begin{array}{l}\text { High concentrations of proteins in } \\
\text { sample would precipitate during } \\
\text { derivatization process }\end{array}$ & $\begin{array}{l}\text { Sensitive to bioassay conditions } \\
\text { (e.g. } \mathrm{pH} \text {, growth condition, borate } \\
\text { concentrations) }\end{array}$ \\
\hline
\end{tabular}

Table 2. Strengths and weaknesses associated with the two AI-2 determination methods evaluated in this study.

\begin{tabular}{|l|c|c|c|}
\hline & \multicolumn{2}{|c|}{ HPLC-FLD } & $\begin{array}{c}\text { Vibrio harveyi } \\
\text { BB170 bioassay }\end{array}$ \\
\hline Linear range & $0.01-0.4 \mu \mathrm{mol}^{-1}$ & $0.4-100 \mu \mathrm{mol} \mathrm{l}^{-1}$ & $0.08-1 \mu \mathrm{mol} 1^{-1}$ \\
\hline $\begin{array}{l}\text { Regression } \\
\text { equation }\end{array}$ & $\begin{array}{c}\mathrm{Y}=8.08734 \mathrm{E} 6 \mathrm{X}+44992 . \\
\mathrm{Y}=7.9251 \mathrm{E} 6 \mathrm{X}+28173 \\
1.093\end{array}$ & $\mathrm{Y}=\mathrm{X}^{2.44569} \times 10^{3.1472}$ \\
\hline $\begin{array}{l}\text { Relative standard } \\
\text { deviation (RSD) }\end{array}$ & $25 \%-88 \%$ & $4 \%-17 \%$ & $26 \%-52 \%$ \\
\hline $\begin{array}{l}\text { Correlation of } \\
\text { determination }\left(\mathbf{R}^{2}\right)\end{array}$ & 0.9995 & 0.9992 & 0.9993 \\
\hline $\begin{array}{l}\text { Limit of detection } \\
\text { LOD) }\end{array}$ & $2.3 \mathrm{nmol}^{-1}$ & $11 \mathrm{nmol} \mathrm{l}^{-1}$ & $40 \mathrm{nmol}^{-1}$ \\
\hline $\begin{array}{l}\text { Limit of } \\
\text { quantification } \\
\text { (LOQ) }\end{array}$ & $6.9 \mathrm{nmol}^{-1}$ & $35 \mathrm{nmol} \mathrm{l}^{-1}$ & $80 \mathrm{nmol}^{-1}$ \\
\hline
\end{tabular}

This article is protected by copyright. All rights reserved. 


\section{Supporting information legends}

Figure S1. Possible isomers of 4,5-dihydroxypentane-2,3-dione (DPD) as illustrated by (Guo et al., 2015). Compounds highlighted in pink show AI-2 activity when determined by Vibrio harveyi BB170 bioassay are generally considered as AI-2 signals. Phosphorylated form of the blue compounds are involved in AI-2 signaling system.

Figure S2. Derivatization reaction of 4,5-dihydroxypentane-2,3-dione (DPD) with 2,3diaminonaphthalene illustrated by (Song et al., 2014).

Figure S3. Schematic of pilot scale cooling tower (PCT) system and two sampling points (marked with yellow stars) used for AI-2 determination in this study. Figure was adapted from schematic illustration drawn by Al-Bloushi et al, 2017.

Table S1. Seawater samples determined for AI-2 signals.

(A)

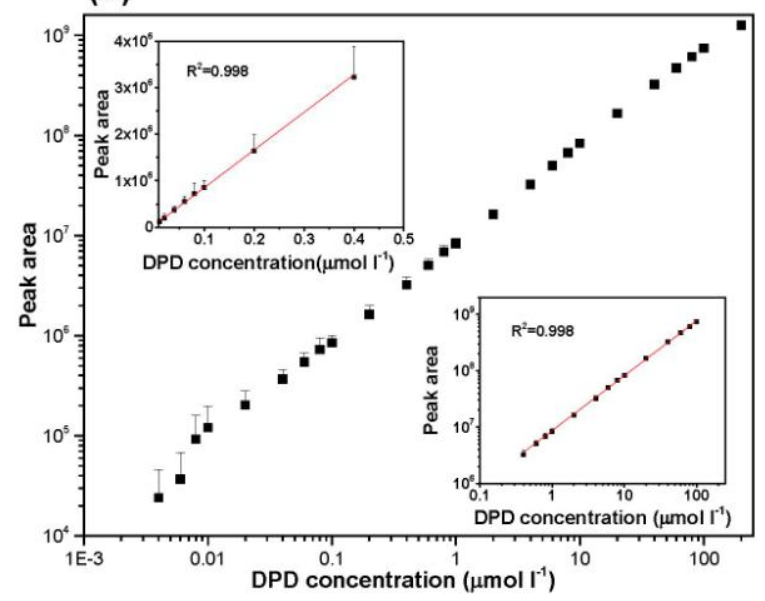

(B)

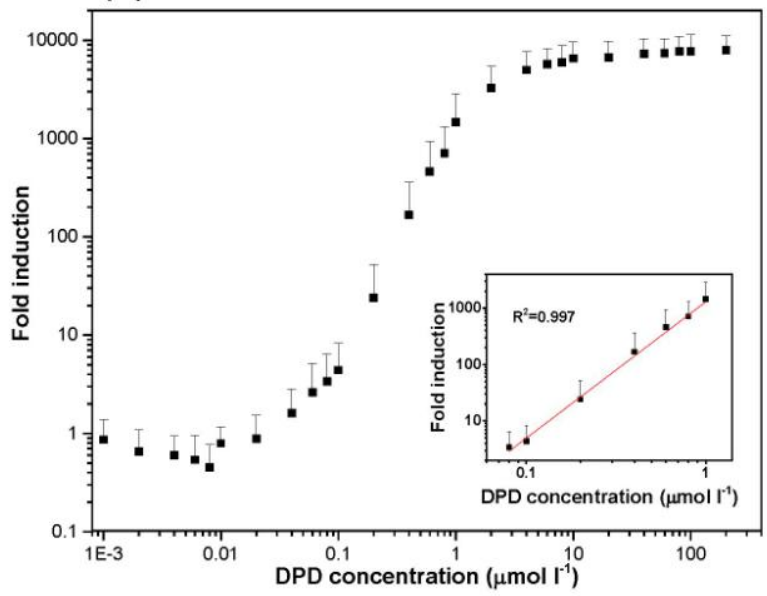

This article is protected by copyright. All rights reserved. 


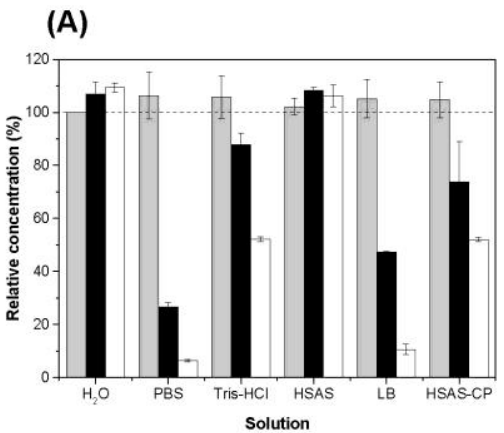

(B)

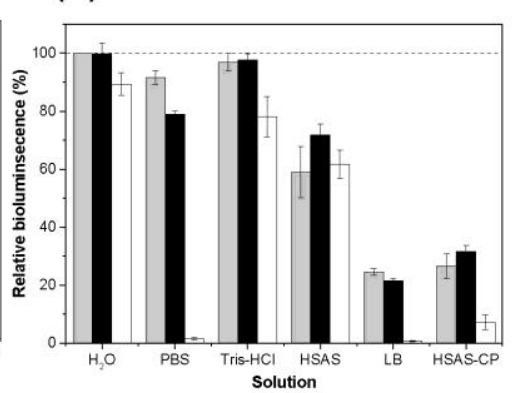

(C)

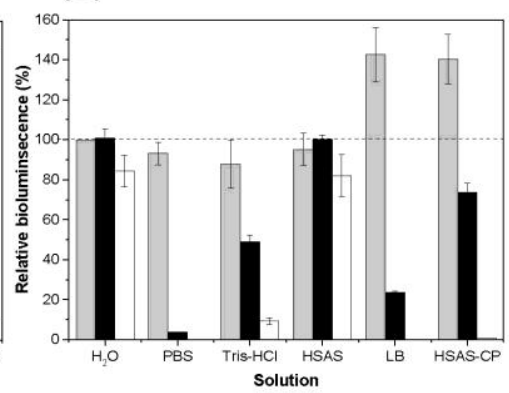

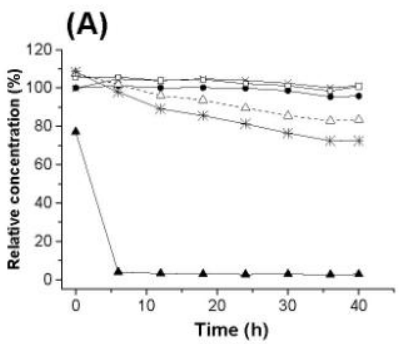

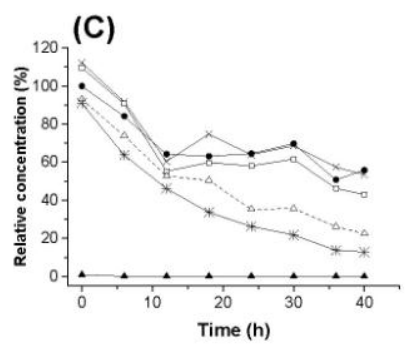

(B)

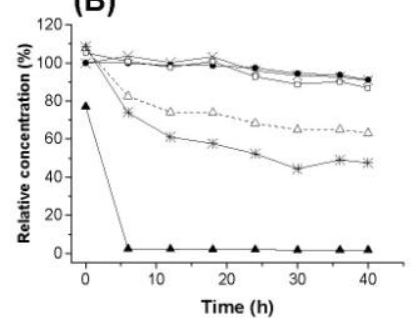

(D)

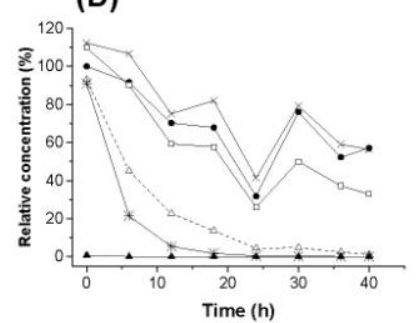

This article is protected by copyright. All rights reserved. 
(A)

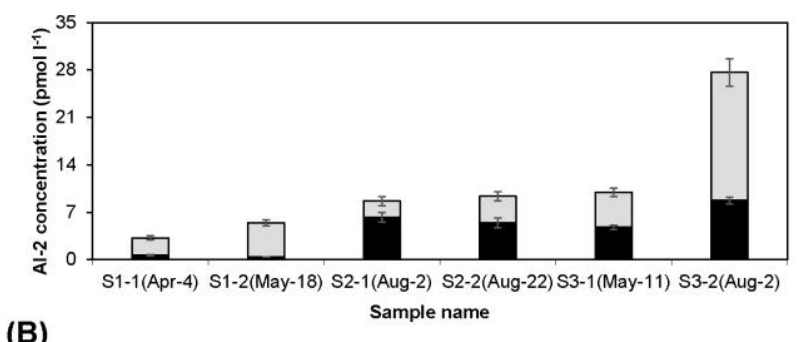

(B)
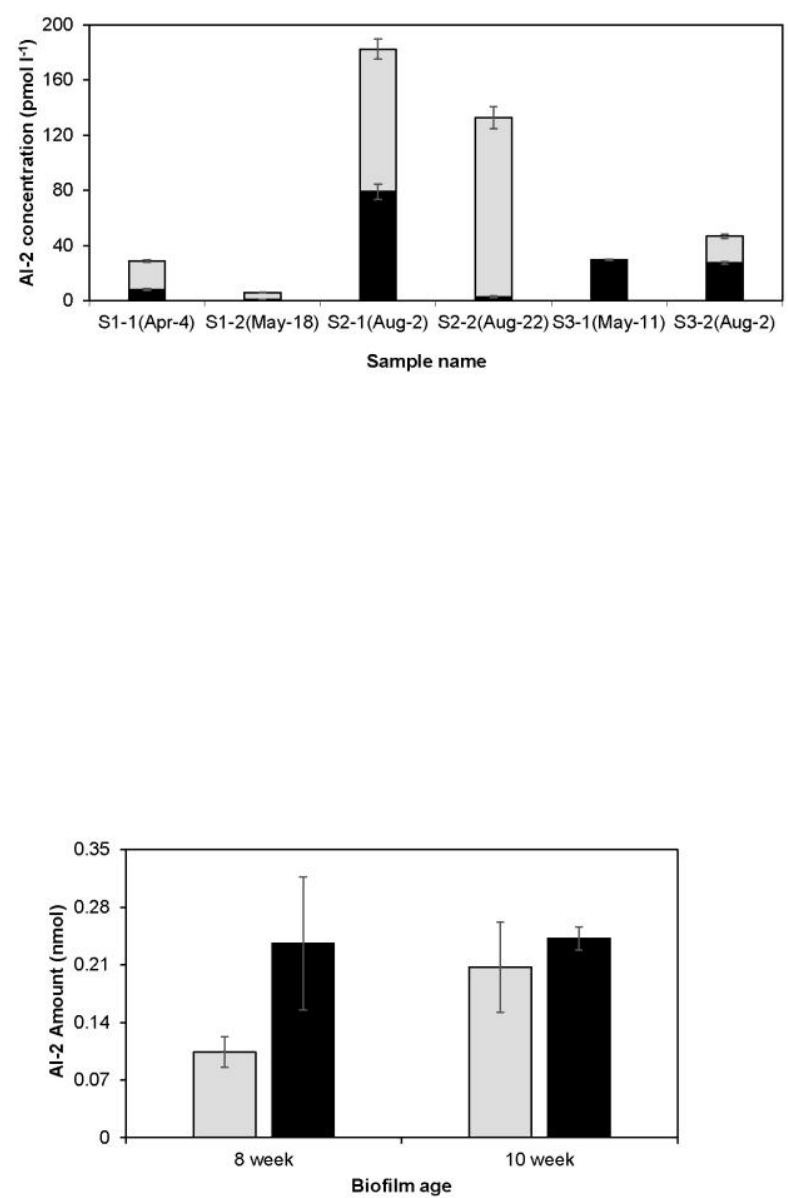

This article is protected by copyright. All rights reserved. 